\title{
Geo-Spatial Analysis of Oil Spill Distribution and Susceptibility in the Niger Delta Region of Nigeria
}

\author{
Shittu Whanda*, Olalekan Adekola, Bashir Adamu, Sani Yahaya, Prem C. Pandey \\ Environment and Safequard Unit, Nigeria Erosion and Watershed Management Project (NEWMAP), Gombe \\ State, Nigeria \\ Email:"shittuwhanda@yahoo.com, lekola1@yahoo.com, ba108@le.ac.uk, yasani2474@gmail.com, \\ prem26bit@gmail.com
}

Received 2 June 2016; accepted 23 July 2016; published 26 July 2016

Copyright (C) 2016 by authors and Scientific Research Publishing Inc.

This work is licensed under the Creative Commons Attribution International License (CC BY). http://creativecommons.org/licenses/by/4.0/

(c) (i) Open Access

\begin{abstract}
Oil spill occurrence during exploration, production and distribution can cause deleterious impact on the environment. Contamination of local streams/rivers, farmlands, forest resources and biodiversity in oil producing areas presents strong significant possibility of significant harm to human health. Geo-information technologies present new opportunities for assessing stress environment and ways of determining exposure susceptibility in such areas. The study assesses the geographical distribution of oil-spills cluster and pattern using three geospatial techniques with ground data at 443 oil-spill incident sites from 1985-2008. The places with high (high-volume/ large impact/close proximity to communities) and low incident (low-volume/less impact/fardistance) are related to the quantity of oil-spills identified within those communities considered susceptible to spill impact and possible exposure. While the average nearest neighborhood analysis showed a probability that oil-spill distribution in the area is clustered (ratio $<1$ with index value 0.19), the Getis-Ord General G test indicated that the oil-spill with high quantities (volume) discharge are significantly clustered within every $400 \mathrm{~m}$. The Moran's $I$ index indicted that there is $<1 \%$ likelihood that the clusters are as a result of random chance. These findings will help to combat the environmental problems and risks of prolong exposure to petroleum hydrocarbons by addressing future incidents or relocating oil facilities/communities and positioning of rapid response strategies.
\end{abstract}

\section{Keywords}

Oil Spills, GIS Analysis, Third Party Damage, Interdiction, Pollutant Linkages

\footnotetext{
${ }^{*}$ Corresponding author.
}

How to cite this paper: Whanda, S., Adekola, O., Adamu, B., Yahaya, S. and Pandey, P.C. (2016) Geo-Spatial Analysis of Oil Spill Distribution and Susceptibility in the Niger Delta Region of Nigeria. Journal of Geographic Information System, 8, 438456. http://dx.doi.org/10.4236/igis.2016.84037 


\section{Introduction}

Oil spills are frequent in oil exploration, refining and processing units [1], thus subjecting oil producing communities to unprecedented environmental degradation [2]. In the last decades, there were several incidents of oil spills in places like the Gulf of Mexico, Canadian marine waters [3] and Prince Williams Sound to mention a few. According to [4] by 1884, nearly 200 small refineries were operated in the suburbs of Baku leading to the emergence of places like the Apsheron Peninsula as the world's first example of oil pollution and environmental negligence [5]. When oil spills occur in the environment it is difficult to recover all, some quantities remain. The Exxon Mobil environmental performance report in 2003 buttressed this much, when it revealed that of about 9100 barrels of oil spilled on soil and water; only a little over 60 percent was recovered [6]. Even though the company claimed that majority of the spills did not affect third parties or communities around operation areas. In a similar incident in 1989, the Exxon Valdez [7] super-tanker which was ran aground at Alaska's Prince William Sound was reported to have discharged more than 250,000 barrels of oil into the environment [8]. The oil spill cost the company $\$ 4.3$ billion on compensatory payment, clean-up payment, settlement, and fine [9]-[11]. These oil spills caused harmful impact on birds and mammals living in the affected areas [12], and arctic marine mammals due to climate change [13]. A report from the Nigerian National Petroleum Corporation (NNPC) in 1983 and corroborated by the United Nations Environmental Program (UNEP) report on pollution in Ogoniland revealed that oil contaminants have spread farther and penetrated deeper into the soil horizon from oil operation that has been going on in the region for over 50 years [14]. Consequently the Niger Delta is now considered the world's most widely contaminated area that will require long term clean up and restoration effort.

Fixed-point hazards such as pipeline oil spills are of great significance to nearby communities, constituting more problems where poverty already affects the population [15] [16]. The frequency and risk of these terrestrial oil spills [17] [18] have great impact on the physical and human environment [19] [20]. The distributions of cost and benefit of oil production are also a major factor in the problems associated with oil spills, while the benefit of spending less on maintenance of transportation systems only increases chances of oil spill incidents on the long run [21] [22]. Most times, the operators do not regularly maintain their pipelines or in most case conserve funds by budgeting less on maintenance, thereby giving raise to the question of pipeline integrity [2]. Although the cost of transportation may seem less with higher benefit, the resultant implication of this sort of approach is higher incidence of oil spills caused by systemic failure and environmental stress.

There is a general concern on the hazards associated with oil and gas activities, especially on how production activities and pollution entrench environmental injustice [19]. Within the literature on environmental justice there is growing concern about the health impact associated with intensive oil and gas activities in many communities [23] as well as concentration of these occurrences in poor communities [24]. Oil spill contamination is currently causing serious environmental and ecological challenges [25] in the Niger Delta, with direct impact on ecosystem services and socio-economic wellbeing of local inhabitants [21]. The human health impact from prolong exposure to petroleum hydrocarbon contaminants, loss of land use space to petroleum production activities and oil pollution has undoubtedly affected the sustainable development of oil producing communities in the Niger Delta. Oil spill impact can affect fishing industries [26], tourism and recreation, and socio-economic condition of humans. The people's health could be adversely affected by petroleum hydrocarbon contaminants due to exposure through; inhalation, ingestion and dermal contact with oil contaminated substances and food materials [27]. The oil and associated hydrocarbons can lead to death from hypothermia, smothering, drowning, and related diseases [28] such as cancer.

The common cause of oil spill is operational failure (pipeline corrosion, production, poor infrastructure and inadequate maintenance, fault during oil processing steps), third party interference (interdiction; the attempt of theft or intentional vandalism) and unknown factors [29] [30]. Accidental Third Party Damage (TPD) of pipelines during excavation is common in most parts of the world, but recently, intentional TPD linked to sabotage and illegal bunkering has been reported in places like Mexico, Colombia, Middle East, Asia and Africa [2]. "Interdiction" is a word used to describe deliberate act of attack, vandalism and/or sabotage [31] [32]. Interdiction has been reported on pipelines around the world; for instance in Indonesia, United States of America, United Kingdom, Canada, Iran, Iraq, Russia, former Soviet Union, Colombia, Saudi Arabia etc. [33]. Repeated sabotage of pipelines supplying Israel and Jordan from Egypt has also been reported [34]. Africa and specifically Nigeria have suffered unprecedented pipeline interdictions, with oil companies like Shell Petroleum Development Company (SPDC) recording an average of about 200 oil spill incidents every year since 2005 [35] [36]. In fact 
[37] alluded to the existence of gangs going from one community to other vandalising pipelines in order to impede oil companies' ability to operate smoothly, while demanding compensation for farmlands and rivers polluted by oil spills. [36] claimed that about 324,000 barrels of crude oil was spilled in 1500 incidents from its facilities from 2007-2013; 75\% of these spills were attributed to sabotage/theft. The main source of spills in the region is the pipelines used for crude transportation, which plays very significant role in oil spill incidents [30] [38]. Since the main purpose of a pipeline is for liquid transportation, any damage can cause serious oil spill incident. Even at that, there are thousand kilometres of onshore pipelines traversing oil producing regions for collecting, distributing and redistributing large quantities of crude oil across the world [29].

With little attention paid to onshore oil spills in developing countries compared with offshore oil spills [39][41], several oil spill incidents in remote rural areas in especially the Niger Delta have gone unreported [2]. These problems are particularly acute in most places due to lack of application of latest techniques or not fully explored. The lack of adequate information on oil spill incidents can be associated with increasing deaths, as people get exposed to toxic hydrocarbons indirectly (dermal contact) and directly (ingestion and inhalation process) [19]. Thus having proper understanding of the pattern of oil spills enables forecasting, spatial analysis is an important technique in addressing some of the challenges posed by these oil spills. The spatial analysis of the oil spill's geographical distribution, pattern analysis, cluster or dispersion is used to assess the potential impact of long term exposure by oil producing communities. It can also help combat environmental pollution, identify potential exposure pathways and possible source of pollution in relation to sensitive areas around oil production sites or prevent fire or related hazards as well as in the preservation of agricultural land, coastal and water bodies in susceptible areas. Therefore, in this paper, the spatial distribution of onshore oil spills in an oil producing area in the Niger Delta region of Nigeria is analyzed using geospatial techniques, to determine quantity of oil spilled, pattern of oil spill distribution and community susceptibility to petroleum hydrocarbon contamination and exposure. Understanding these would help regulators and operators in the oil and gas industry to address problems of social and environmental justice through appropriate allocation of scarce resources for rapid response, exposure mitigation, distribution of cost and benefit and promote community level participation for sustainable development.

\section{Description of the Study Area}

This section describes the geographical extent, demography, physical characteristics, and socio-economic condition of the study area. The present research was conducted in the Niger Delta (see Figure 1) region of Nigeria, which has over 37 million inhabitants, constituting about 22\% of Nigeria's population [42] with a population density of 265 per square km. The oil and gas resources of the Niger Delta accounts for over 85\% of Nigeria's gross domestic product (GDP), over 95\% of the national budget, and over $80 \%$ of the nation's wealth [43]. The Niger Delta region is made up of nine states with more than 1500 communities hosting several oil and gas companies [44]. The region is ethnically varied and diversified with socio-political strength [45]. The region is generally rural, with few major towns like Port Harcourt, Warri and Asaba. The inhabitants live below the poverty line and rely on subsistence fishing and agriculture for survival [46]. The region is home to the oil wealth that made Nigeria the highest producer of petroleum in Africa, and the sixth in the world [47].

Commercial crude oil drilling started in Oloibiri village in 1958. Frequent incidents of oil spills have exposed the region's environment and inhabitants to serious health risk. [45] estimated approximately 6800 spills incident leaking about 3000,000 barrels of oil from 1976 to 2001. A similar report by [48], showed that there were 253 oil spills in 2006, 588 oil spills in 2007 and 418 incidences in the first six months of 2008.

\subsection{Geographical Extent}

The Niger Delta is located in the southern part of Nigeria, bordering the Gulf of Guinea (Atlantic Ocean). The specific study area is located on longitude $5.05^{\circ} \mathrm{E}$ and $7.35^{\circ} \mathrm{E}$ and latitude $4.15^{\circ} \mathrm{N}$ and $6.01^{\circ} \mathrm{N}$, covering approximately $1294 \mathrm{~km}^{2}$ [49], which represents about $7.68 \%$ of Shell's area of operation estimated at about $16,842 \mathrm{~km}^{2}$. The River Niger is the principal river in West Africa and the third largest water course in the continent, originating from Futa Jallon highlands in Guinea, flowing for over $4184 \mathrm{~km}$ in the north-east through Mali to the south east then linking Niger before running into Nigeria where it forms it largest tributaries with River Benue in Central Nigeria. The river continues towards the south of Nigeria for about $400 \mathrm{~km}$ to form a fan-shaped delta and finally empty into the Gulf of Guinea. 


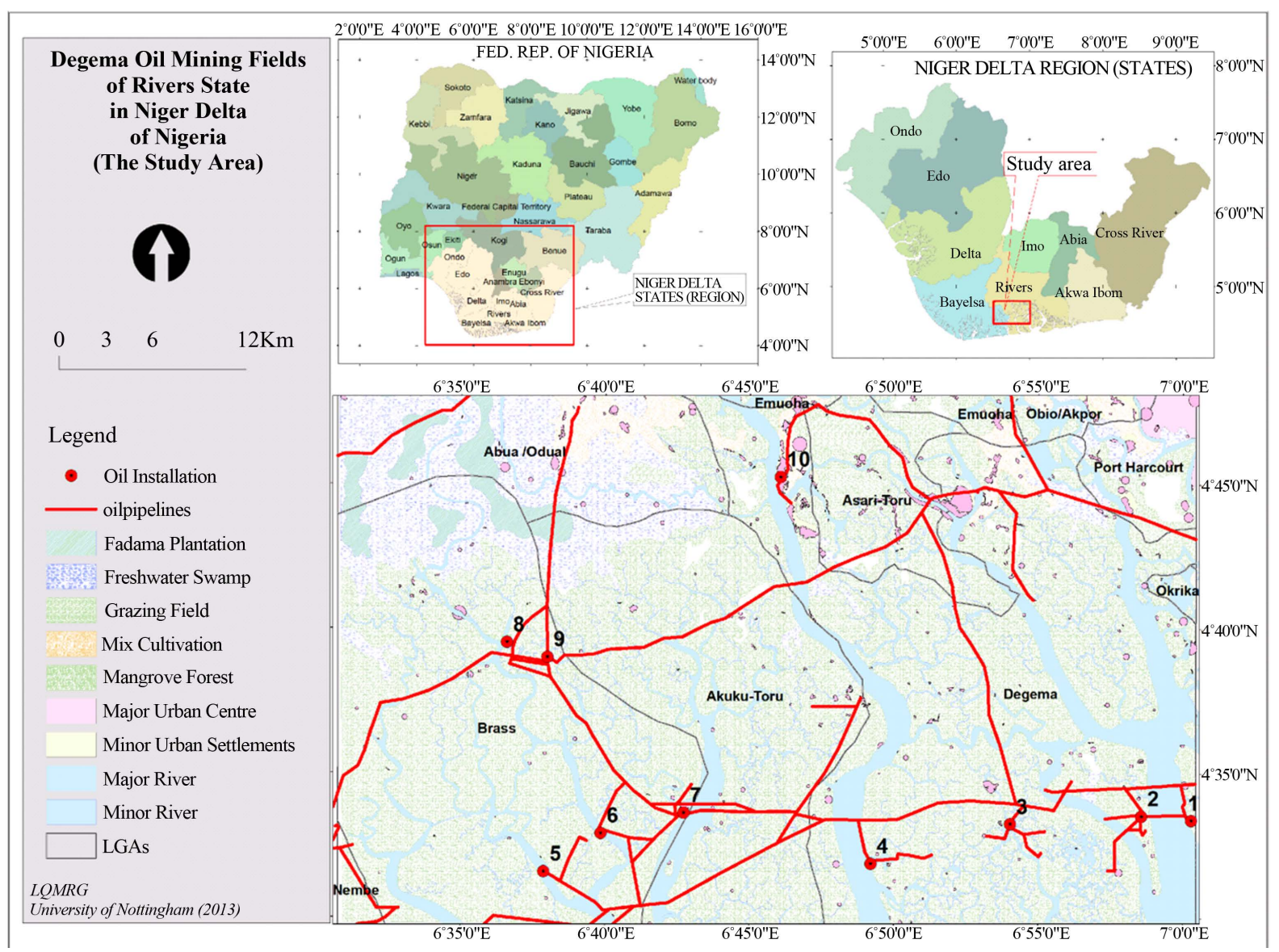

Figure 1. Location of the 374 communities across 8 adminstrative local government areas (LGAs) in Rivers state in the Niger Delta region of Nigeria also showing pipeline network.

\subsection{Physical Characteristics}

Geologically, the study area is characterised by rain fed deltaic vegetation in places with high elevation, majority of the region is dominated by low-lying landforms. The soils found in this zone do not depend highly on climate and vegetation for their formation as most are the result of series of alluvium deposition over centuries ago. Most of the drilled wells in the coastal areas produce brackish (salty) water (not good for consumption) in some cases below $200 \mathrm{~m}$ from ground level; this could be due to oil contamination of the groundwater or fresh and salt water interaction. The surface water is drained by river systems mostly linked with channels and streams that are subjected to oil pollution in the upstream sections. The freshwater and deltaic estuaries (an area of interaction between fresh and sea-water) covers approximately $3600 \mathrm{~km}^{2}$ and $6170 \mathrm{~km}^{2}$ respectively, these mostly flow from the River Niger and inland tributaries during the rainy season and backflow during the dry season due to tidal variation [50]. The vegetation generally consist of wide variety of trees and plants that include mangrove of different kinds, grasses, herbs and climbers, all attributed to the depositional nature of the shoreline [51]. Report on Ogoniland gave serious insight on the magnitude of oil impact on the vegetation. The topography of the Niger Delta or Nigerian coastal areas is generally low-lying at about $2 \mathrm{~m}$ to $4 \mathrm{~m}$ above sea level [50]; this alone is an important factor that could influence oil spill migration.

\subsection{Socio-Economic Conditions}

[52] studied the socio-economic impacts of oil exploration activities on the local communities and their livelihood. They argued that oil development in the Niger Delta has dramatically changed the local communities, and brought challenges to their traditional economic, cultural, and daily living conditions. Although crude oil production has boosted Nigeria's economy, the trickle down effects are hardly felt by ordinary members of the host 
communities. Studies have shown that oil exploitation has had serious implications on the socio-economic wellbeing of the area. This includes loss of farms, fishing and other related businesses such as boat charters for tourist are affected. Many local economies have been destroyed; the increasing poverty rates have also impoverished the already poor communities [53]. Oil spills have not only caused damage to socio-economic activities of the communities, it has also caused food shortage due to the destruction of farmlands by oil pollution.

\section{Materials and Methods}

The spatial distribution of oil spills sites provided a means for determining communities likely to become susceptible to petroleum hydrocarbon contamination. For this assessment, communities in the area were treated as surrogate for human population and settlement while land, vegetation and rivers were considered the medium of land use. The thiessen polygon was developed in ArcGIS environment to demarcate boundaries of the communities (since no community boundary shapefiles is available) and determine the number of spill sites in each thiessen polygon that represents a community. Theoretically, any point in a given thiessen (voronoi) polygon is closer to the centroid of that polygon than any other point, therefore the nearest community is more susceptible [1] [54]. Thus, it is assumed that any oil spill (point) in a polygon is associated with that community. Table 2 represents the first 20 communities with the highest number of repeated oil spill cases in the period under study.

\subsection{Type of Data and Source}

The data used in this study includes GPS data of 443 oil spill sites from 1985-2008, oil spill record and pipeline map layers acquired from the Department of Petroleum Resources in Nigeria (DPR, is the regulatory agency of oil and gas activities in Nigeria). In all, the data consist of about 374 communities across eight administrative local government areas (LGAs) of Rivers state in Nigeria (see Figure 1). A SPOT Satellite image was used to identify settlements and other land use in and around oil facilities. The pipeline system was digitised from the SPOT image to further augment identification of additional pipelines (not present in the earlier shapefile acquired from DPR), oil installations and to determine proximity of communities to pipelines. A total of $314.3 \mathrm{~km}$ of pipeline network connecting flow-stations and storage terminals were identified from the DRP data and the SPOT image. The data were used to assess the oil spill spatiotemporal distribution and determine exposure susceptibility in the area. The oil spill datasets contains information on geo-coordinates of individual oil spill sites, date of spill, date of survey and quantity of crude oil discharged. From this information, the following statistics were obtained e.g. minimum crude ( 2 barrels) discharged on the $26^{\text {th }}$ of August, 2003 and the maximum spill of 3500 barrels which was discharged on the $24^{\text {th }}$ of June, 2002. In terms of frequency of spills, the year 1985 recorded a minimum of three incidents while 2007 had the maximum of 46 spills. Figure 2 shows the oil spill frequency and quantities spilt from 1985 to 2008.

\subsection{Type of Data and Source}

The following analysis was performed: Spatial Analysis description for Average Nearest Neighbour Analysis, Getis-Ord General G tests for High and Low Cluster, Spatial Autocorrelation Analysis (global Moran's I), and Cluster and Outlier Analysis in the study. These spatial analyses were undertaken to measure the spatial pattern and relationship between features that are spread over a given geographical region [55]. The methodology of four spatial analysis techniques has been illustrated in Figure 3. It helps in assessing and determining the closeness and patterns of the oil spill sites near settlements. The methods generated geographical distribution, cluster and pattern analysis of oil spills and spatio-temporal nature of the oil-spill incidents. No specific criteria were adopted in choosing the time interval or grouping of the spill period in the analysis.

\subsubsection{Average Nearest Neighbour}

This method is uses index number to determine if the nature of distribution is random or not. The index number is the difference between the observed and the expected mean distances of a random distribution [56] [57] derived by dividing the observed distance with the expected distance. By adding all distances between pairs of nearest neighbours and dividing same with the number of features in a set, the observed mean distance is obtained. Expected mean distance on the other hand is a hypothetical random distribution generated by default [56] [57]. Equations (1) to (5) are used in the average nearest neighbour procedure. When the index ratio is $=1$, the distribution is random; if it is $>1$, the distribution is disperse; but if it is $<1$, the distribution is cluster [55] [57]. 


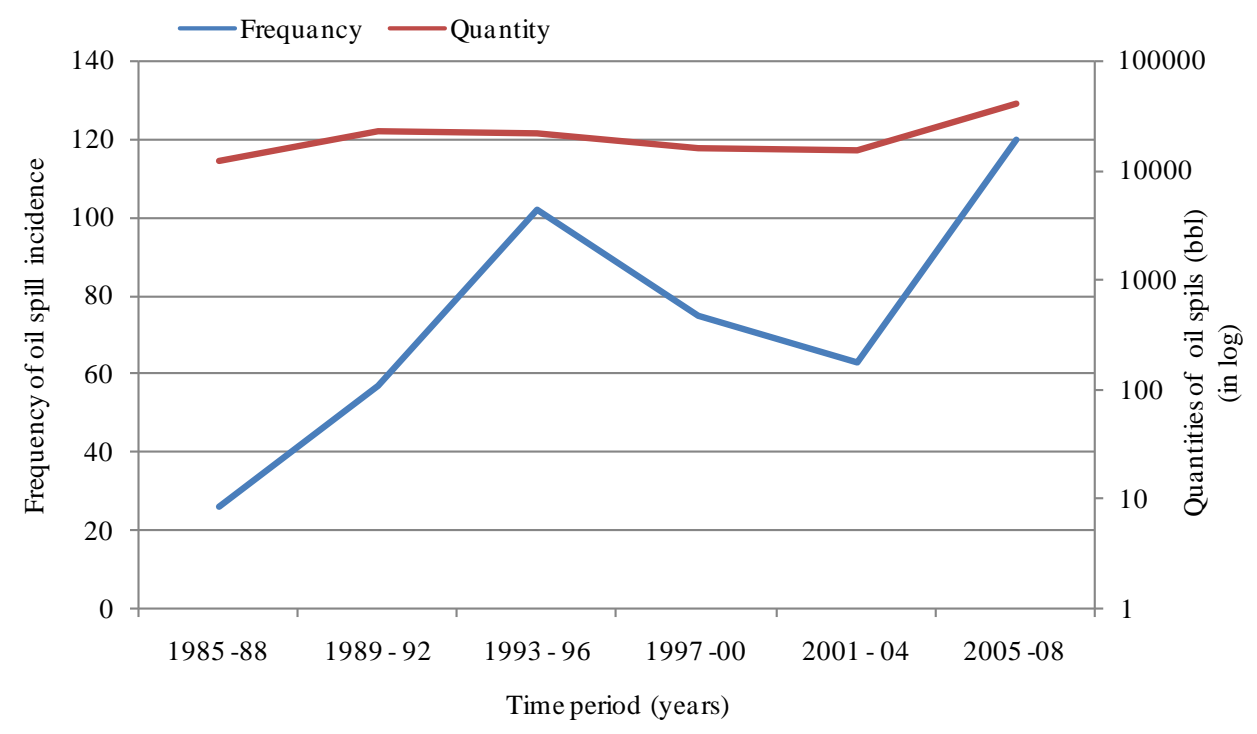

Figure 2. Distribution of oil spill frequency and quantity spilt in log over time-period (1985-2008).

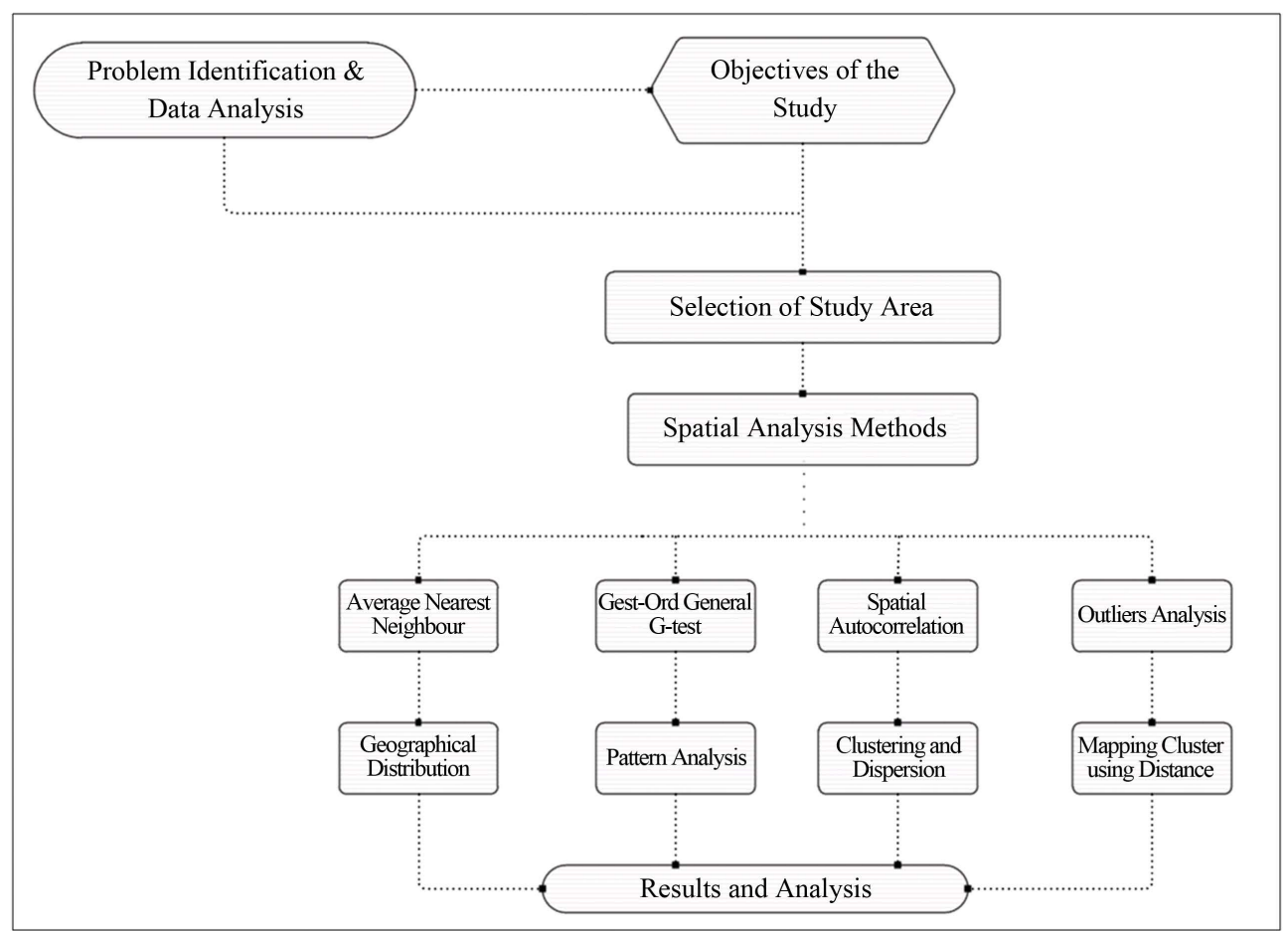

Figure 3. Flow chart for the methodology adopted for the study showing four spatial techniques resulting in diferent analysis.

$$
A N N=\frac{\bar{D}_{O}}{\bar{D}_{E}}
$$

where: $\bar{D}_{O}$ is the observed mean distance between features and their nearest neighbours derived by Equations (2) and (3).

$$
\bar{D}_{O}=\frac{\sum_{i=1}^{n} d_{i}}{n}
$$


$\bar{D}_{E}$ is the expected mean distance between the features derived.

$$
\bar{D}_{E}=\frac{0.5}{\sqrt{n / A}}
$$

$A$ is the study area, $d_{i}$ is distance between feature $i$ and its nearest neighbour, while $n$ is the total number of features.

$$
Z_{A N N}=\frac{\bar{D}_{O}-\bar{D}_{E}}{S E}
$$

where $S E$ is the standard error of the mean nearest neighbour distance [56] and 0.26136 a mathematical constant derived from the radius of a circle [57]. SE is derived by Equation (5):

$$
S E=\frac{0.26136}{\sqrt{n^{2} / A}} .
$$

\subsubsection{Getis-Ord Genral G Test}

This method provides a way for locating hot spots (clusters of high values) and cold spots (cluster of low values). The calculation is based on a neighbourhood distance within which cluster is expected to occur [58]. This is based on the frequency of the oil spill incidents happening around the settlement, locating them as either high values of oil spills incidents or low values using Equations (6) and (7).

$$
G(d)=\frac{\sum_{i} \sum_{j} w_{i j}\left(X_{i} \cdot X_{j}\right)}{\sum_{i} \sum_{j}\left(X_{i} \cdot X_{j}\right)}
$$

where $G(d)$ the General $G$-statistic for a distance is $(d), X_{i}$ is the value of the target feature, $X_{j}$ is the value of each neighbour and $w_{i j}$ is the weight of the pair.

$$
Z_{G(d)}=\frac{G(d)_{o}-G(d)_{E}}{S D_{G(d)}}
$$

where $Z_{G(d)}$ is the $Z$-score for $G$-statistics at distance $(d) ; G(d)_{0}$ is the observed $G$ distance; $G(d)_{E}$ is the expected $G$ distance; and $S D_{G(d)}$ is the standard deviation for the expected $G$ for that distance [59].

General $G$ shows the type of cluster that exist (part of an area there are clusters of high values than other parts). General $G$ measures the concentration of a parameter (oil spills), for example identifying the location where the largest number of oil spills are [59]. This method provide basis for determining the probability of cluster and random distribution without visual display.

\subsubsection{Spatial Autocorrelation Analysis (Global Moran's I)}

This method measures clusters by location and value (quantity). Thus, it is able to identify whether quantity discharged has influence on cluster or not, using the Moran's I function. Moran`s only shows data is clustered, dispersed or random (pattern detector). Moran Statistics generate the results to local diversity with significance z-score and identifies those clusters of points with values similar in magnitude and those clusters of points with very heterogeneous values. Since the oil spills are in points features, this method adopted techniques to convert them in to polygon for carrying out the analysis. The converted polygon is presented in a grid cell of $100 \times 100$ meters that was created to count spills in each polygon using spatial join command in ArcGIS. By comparing the value for neighbouring spills, a difference between each pair of spills was obtained and cluster determined by locating the highest Z-Score for the polygon concerned according to Equations (8) and (9).

$$
I=\frac{n \sum_{i} \sum_{j} W_{i j}\left(X_{i}-\bar{X}\right)\left(X_{j}-\bar{X}\right)}{\sum_{i} \sum_{j} W_{i j} \sum_{i}\left(X_{i}-\bar{X}\right)^{2}}
$$




$$
Z_{I}=\frac{I_{o}-I_{E}}{S D_{I_{E}}}
$$

where $Z_{I}$ is the Z-score for Moran's $I, I_{o}$ is the observed $I$ and $I_{E}$ is the expected $I$ value. $S D_{I_{E}}$ is the standard deviation of $I$ expected distribution.

p-values are the probability and z score is the standard deviation of the spatial distribution of the oil spill incidents. The p-value is a numerical approximation of the area under the curve for a known distribution, such as numerical values of oil spill's spatial distribution areas falling under the curve for the study site. Wherever there is very small p-value, it means it is very unlikely (small probability) that the observed spatial pattern is the result of random process, therefore the null hypothesis is rejected. Generally, the tails of the distribution have very high or very low z-score and that too is associated with very small p-values. When a pattern analysis tool is operated and it results in small p-values with either very high or very low z-score, it is an indication that it is unlikely that the observed spatial pattern is a reflection of the theoretical random pattern represented by null hypothesis. Thus, if the $\mathrm{Z}$ score value is positive, it means that high values are cluster together, but if the $\mathrm{Z}$ score value is negative, it means that the low values are cluster together.

\subsubsection{Outlier Analysis}

This technique uses critical values (Z-score) to determine spatial relationships and/or distribution between oil spill sites and communities. This technique is considered better than the Getis-Ord General G test or the others as it produce map for visualization. Using this technique in ArcGIS environment will result in the creation of layer attributes and table for display and map symbology. Thus, in this way, a cluster pattern is examined using graphical display and map overlay of Outliers Spatial Analysis [60] [61]. Moreover, it provides feature pattern for analysis and display location of cluster in the results. In turn, locations which are identified as high cluster are assumed to be "hot spots" and low clusters as "cold spots".

\subsection{Characteristics of the Oil Spill}

To determine the characteristics of spill incidents, the spills were analysed according to factors, frequency and quantity. Although there are several causes of oil spills in literature, the causes considered in this analysis are categorised into four; namely corrosion, production error, interdiction and unknown factors. The reason for the high frequency and low discharge attributed to production error may likely be linked to workers immediate response, which minimises the quantity of oil discharged, or that workers underreport quantity of oil spilt from production [2]. Spills by "corrosion" refers to those caused by internal and external decay of pipes due to old age and chemical reaction; "production error" on the other hand refers to oil spills caused by system failure and human error; "interdiction" on the other hand refers to oil spills caused by intentional TPD such as vandalism, sabotage, bunkering and theft; finally "Others and yet to be determined" are spills whose cause are unknown or undecided by the reporting inspection teams.

\section{Results}

\subsection{Frequency Distribution of Oil Spills}

The results of factors responsible for the oil spills are presented in the 1985-2008 graphs. Figure 4(a) reports the oil spills caused by interdiction where the peaks were observed in 1991, 1993, 2001 and 2007, while the lowest numbers were observed in 1987, 1988, 1989, 1996 and 2004. The oil spills by corrosion has seen a somewhat different trend than the interdiction. The highest peak for the corrosion factor was observed in year 1994 (Figure 4(b)). Whereas, the highest peak for production error was observed in the year 1995 (Figure 4(c)) and unknown factors peaked in 2007 (Figure 4(d)). The spills due to unknown factors showed fluctuations that is sometime no incident of oil spills. The frequency and quantity (severity) of spills showed that interdiction factor discharged the largest quantity of oil spills among all factors, even when it is responsible for less than $32 \%$ of oil spill incidents in the period under examination.

Oil spills due to production error occurred 154 times, which is the highest number, while the lowest corresponding to unknown factors, total 36 (see Table 1). Though, production factors correspond to the highest frequency of oil spills, it discharged almost 3.5 times less than interdiction. This is due to spills from production 


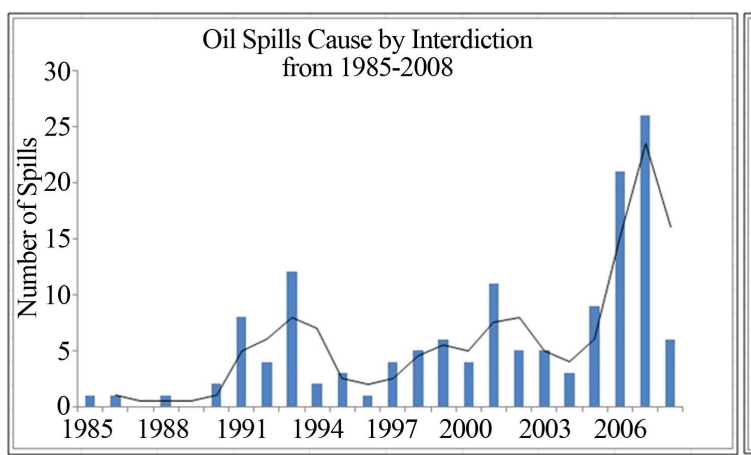

(a) Interdiction

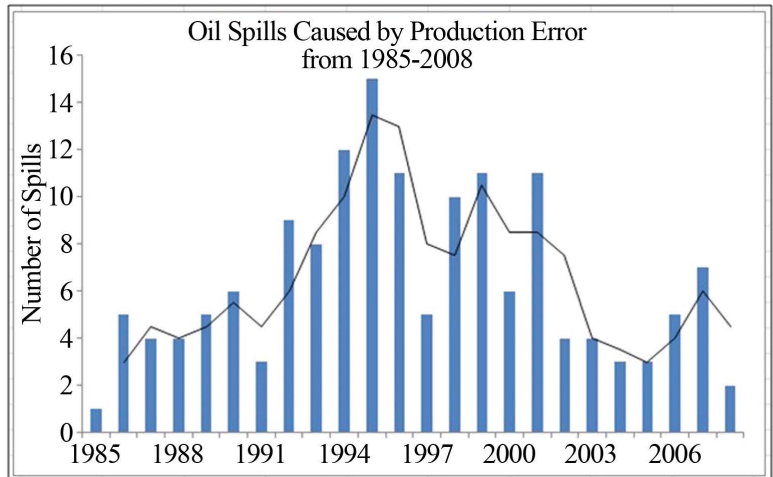

(c) Production Error

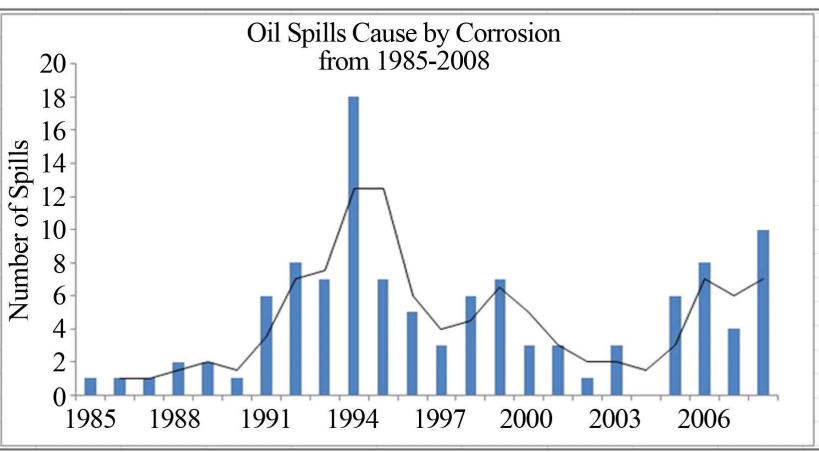

(b) Corrosion

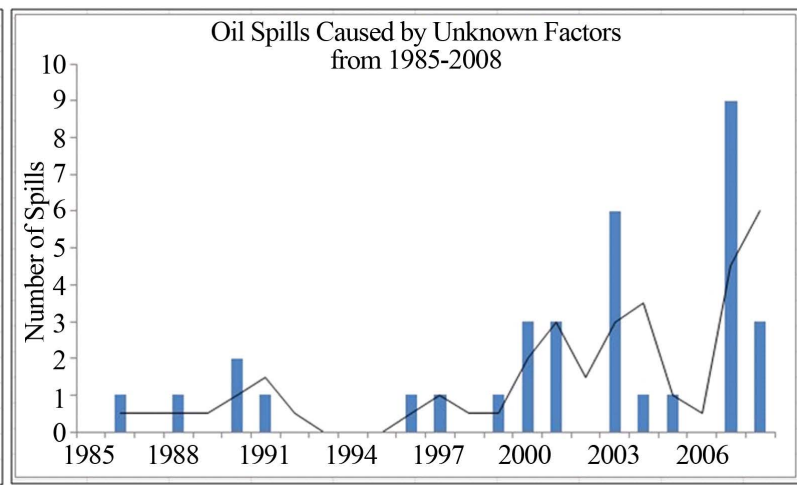

(d) Unknown

Figure 4. Flow chart for the methodology adopted for the study showing four spatial techniques resulting in diferent analysis.

Table 1. Frequency and statistics of oil spills during time interval.

\begin{tabular}{|c|c|c|c|c|c|c|c|c|c|c|}
\hline \multirow{3}{*}{ Period } & \multicolumn{10}{|c|}{ Oil spill characteristics (1985-2008) } \\
\hline & \multicolumn{5}{|c|}{ Cause } & \multicolumn{5}{|c|}{ Statistics in barrels (bbl) } \\
\hline & Corrosion & Others & Production & Interdiction & $Y T D$ & No. & Quant. & Min. & Max. & Mean \\
\hline 1985-1988 & 5 & 4 & 14 & 3 & - & 26 & 12259 & 27 & 2761 & 471.5 \\
\hline 1989-1992 & 17 & 3 & 23 & 14 & - & 57 & 22980 & 14 & 2134 & 403.1 \\
\hline 1993-1996 & 37 & 1 & 46 & 18 & - & 102 & 21548 & 4 & 2043 & 211.2 \\
\hline 1997-2000 & 19 & 5 & 32 & 19 & - & 75 & 15999 & 5 & 2000 & 212.3 \\
\hline 2001-2004 & 7 & 4 & 22 & 24 & 6 & 63 & 15628 & 63 & 3500 & 248 \\
\hline 2005-2008 & 28 & 1 & 17 & 62 & 12 & 120 & 41164 & 2 & 3012 & 343 \\
\hline Total & 113 & 18 & 154 & 140 & 18 & 443 & 129578 & & & \\
\hline
\end{tabular}

YTD: are yet to be determined cases.

error being under-reported or controlled, while the opposite may be the case with interdiction, where spills must first be discovered and reported before contingency plan is activated [2] [62]. For this reason, it may take longer for operators to dictate on-going spills from interdiction due to ineffective leak detection system and poor spill contingency protocol [2]. The distribution of oil spills caused by all factors did not reveal any definite patterns.

\subsection{Spatial Analysis of Oil Spills}

To establish pattern and evaluate relationships between frequency, quantity and locations of oil spills, the spill incidents are divided into six categories of four years interval (see Table 2). The present study investigates the 
Table 2. List of top 20 communities with the highest total spill incidents in the period.

\begin{tabular}{|c|c|c|c|c|c|c|c|}
\hline Sn & Community & $1985-1990$ & 1991-1996 & 1997-1902 & 2003-2008 & Total & Quant. \\
\hline 1 & RUSSIA & 7 & 21 & 13 & 18 & 59 & 23,219 \\
\hline 2 & ONONGISUO & 2 & 13 & 21 & 9 & 45 & 12,399 \\
\hline 3 & ADERIKIRI & 2 & 9 & 10 & 11 & 32 & 6812 \\
\hline 4 & GOGOBOKIRI & 5 & 12 & 6 & 4 & 27 & 8531 \\
\hline 5 & FESTUSKIRI & 2 & 12 & 5 & 8 & 27 & 6740 \\
\hline 6 & IJAWKIRI & $\mathrm{x}$ & 11 & 1 & 12 & 24 & 10,067 \\
\hline 7 & EGOROBITI & 1 & 10 & 9 & 3 & 23 & 8740 \\
\hline 8 & DAOJUKIRI/ABABO & 3 & 4 & 5 & 2 & 14 & 5021 \\
\hline 9 & АВАВОКМО & $\mathrm{x}$ & 4 & 5 & 3 & 12 & 1432 \\
\hline 10 & ASUMEBUAMA & 5 & 2 & 1 & $\mathrm{x}$ & 8 & 1001 \\
\hline 11 & DAWARI & 4 & 2 & 2 & $\mathrm{x}$ & 8 & 2856 \\
\hline 12 & OPOMAKIRI & 1 & 4 & 3 & $\mathrm{x}$ & 8 & 1666 \\
\hline 13 & OBONOMA & $\mathrm{x}$ & 2 & $\mathrm{x}$ & 5 & 7 & 430 \\
\hline 14 & OKIKIRI & $\mathrm{x}$ & 1 & 2 & 4 & 7 & 416 \\
\hline 15 & OKPO & $\mathrm{x}$ & $\mathrm{x}$ & $\mathrm{x}$ & 7 & 7 & 2261 \\
\hline 16 & BANKIRI & $\mathrm{x}$ & 1 & 1 & 5 & 7 & 2648 \\
\hline 17 & FENIPANGA & $\mathrm{x}$ & 1 & 4 & 1 & 6 & 102 \\
\hline 18 & ETAM KALBAN & $\mathrm{x}$ & $\mathrm{x}$ & $\mathrm{x}$ & 6 & 6 & 365 \\
\hline 19 & OMEKWE-TARI-AMA & $\mathrm{x}$ & $\mathrm{x}$ & $\mathrm{x}$ & 6 & 6 & 1451 \\
\hline 20 & KILLYKIRI & 3 & 2 & 1 & $\mathrm{x}$ & 6 & 1831 \\
\hline
\end{tabular}

pattern and cluster of oil spills distribution using four different spatial analysis techniques to determine the susceptibility of the communities around oil facilities. The outcomes of all four spatial techniques are discussed below:

i) The Average Nearest Neighbour analysis of the spill distribution indicates that there is less than $1 \%$ likelihood that the distribution is random, with an index ratio of 0.19 , and the distribution tends toward cluster with an index ratio of less than 1 at 0.01 significant levels. The observed and expected mean distances are $196.14 \mathrm{~m}$ and $1042.44 \mathrm{~m}$ respectively with a Z-score of -32.69 ; p-value $=0.000$ also at 0.01 significant level.

ii) Getis-Ord General G-test analysis was performed to locate the hot spots (clusters of high values) as well as cold spots (cluster of low values). The calculation is based on a neighbourhood distance within which cluster is expected to occur [58], hence the Distance Band Neighbour (DBN) count was calculated to determine average equidistance for six neighbouring spill sites at $923.96 \mathrm{~m}$ (Min = $0 \mathrm{~m}$, Max. $=14142.6 \mathrm{~m})$. The DBN of 923.96 was rounded to $1000 \mathrm{~m}$ for calculating the General $\mathrm{G}$ test and to determine the extent of Z-scores. The determination of Z-scores and estimation of high and low cluster zones was analysed for $1 \mathrm{~km}$ at $200 \mathrm{~m}$ intervals as shown in Figure 5, which showed that at a distance of $400 \mathrm{~m}$, the Z-score is highest i.e. 0.47 (p-value of 0.63 at 0.10 significant level). This means that there is significant cluster of high quantity spills at every $400 \mathrm{~m}$ within the study sites.

iii) Spatial autocorrelation (global Moran's I), was used to assess the oil spills cluster by location and values. This method was applied for a distance of $1 \mathrm{~km}$ at $100 \mathrm{~m}$ intervals (see Figure 6). Since, the oil spills are in points but the method is suitable for polygons only, we created grid cells of $100 \times 100 \mathrm{~m}$ to count spills in each polygon using spatial join command in ArcGIS. The neighbouring oil spill values were compared, and difference between each pair of neighbouring oil spill values was obtained and cluster determined by locating the highest Z-Score shown in Figure 6. The analysis revealed a general decrease in cluster with increase in distance, so oil spills are inversely proportional to the distance from oil facilities/oil sources. Therefore, it is inferred that 


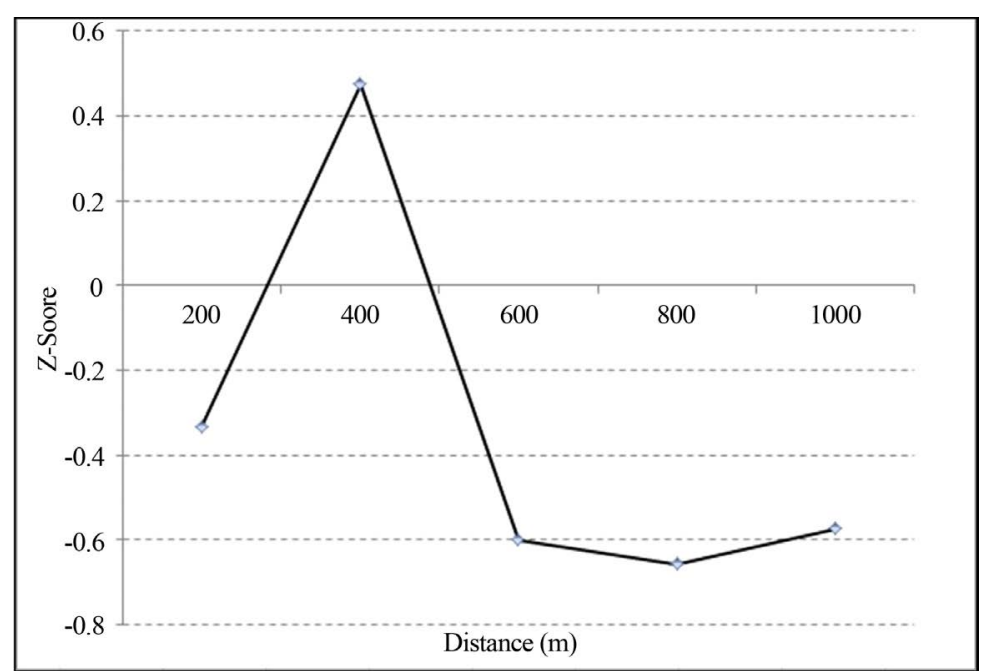

Figure 5. High and low clustered oil spill sites with similar quantities within 200 m interval.

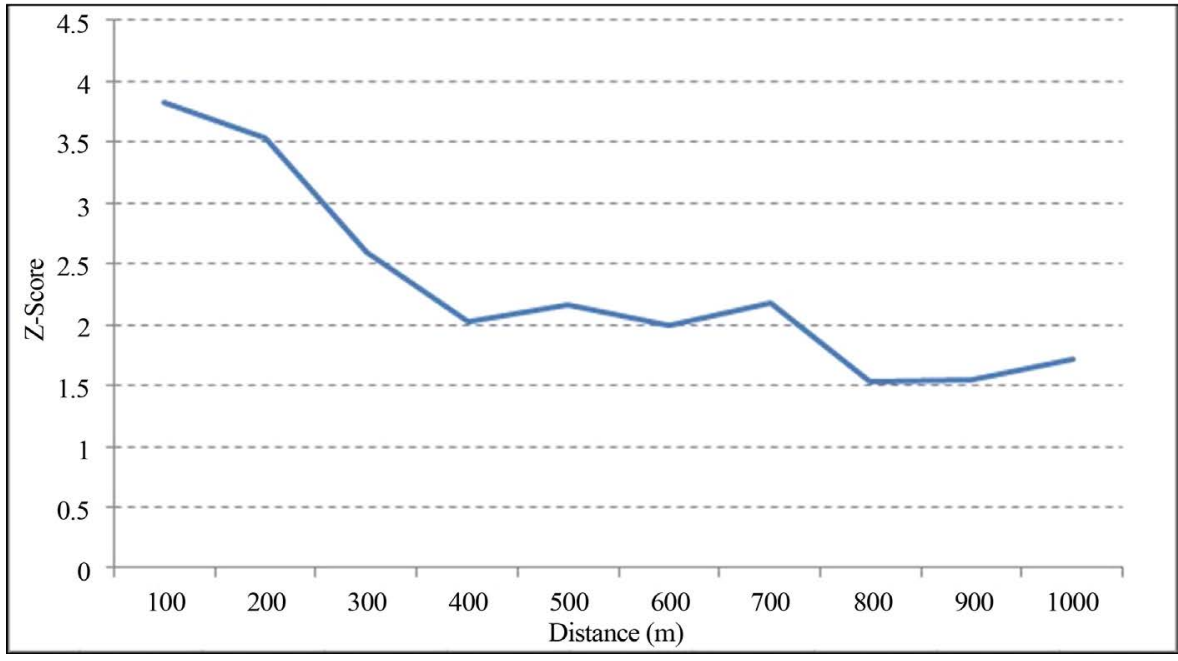

Figure 6. Spatial autocorrelation showing cluster of oil spills by location and quantity at 100 $\mathrm{m}$ intervals.

large quantities of oil spills are found within $100 \mathrm{~m}$ and low quantities oil spills are seen at farthest distance (see Figure 6).

The Moran's index for a $1 \mathrm{~km}$ distance is equal to 1.75 which is greater than 0 . Thus, signifying cluster pattern i.e. "similar values are found together". The highest critical value for $100 \mathrm{~m}$ is 3.83 with p-value = 0.000130 at 0.01 significant level. Given the Z-score of 1.75 at the $1000 \mathrm{~m}$ interval, there is less than $1 \%$ likelihood that the cluster is the result of a random chance and there is high probability of finding larger quantities of oil spills within $100 \mathrm{~m}$. Based on the result, it is safe to assume that there is a very high certainty that the source of spill responsible for discharging such large quantities of crude oil may be located in close proximity e.g. to storage tanks, oil gathering terminals or points of massive interdiction.

iv) Cluster and Outlier Analysis, of the spill pattern and results, revealed the locations with high cluster pattern as "hot spot" and low cluster as "cold spot" as shown in Figure 7(a). The technique identifies clusters with large quantities or high values (denoted by "HH"), small quantities or low value clusters (denoted by "LL"). "HL" denotes large quantities or high value outliers surrounded by low values while "LH" represents small quantities or low value outliers surrounded by large quantities or high values as shown in Figure 7(b).

The cluster and outlier analysis is shown in Figure 7(b), revealing oil spill clusters in terms of quantity according to "HH" and "HL" represents clusters of large quantity of oil spills and outliers surrounded by small 
S. Whanda et al.

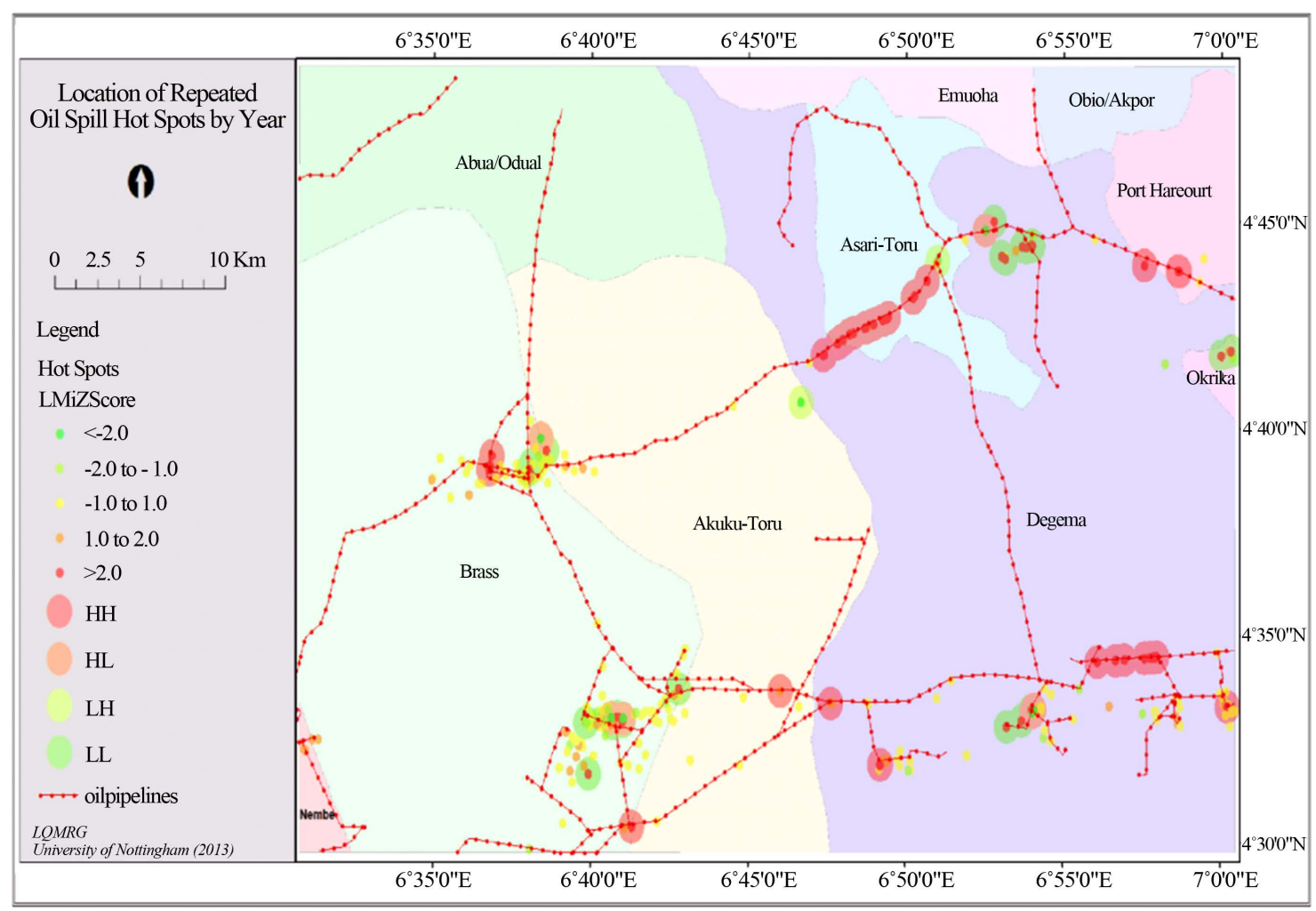

(a)

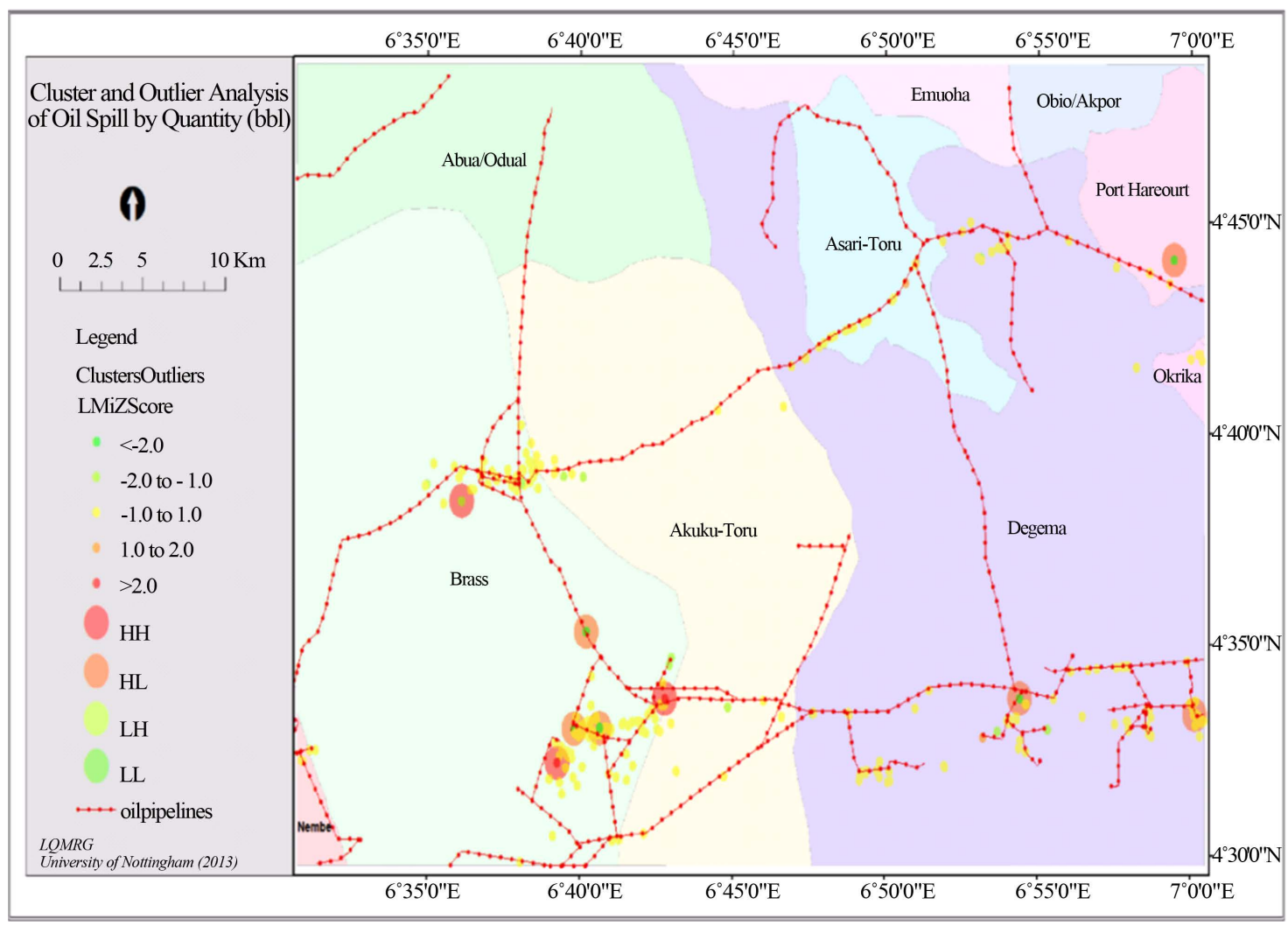

Figure 7. Showing cluster and Outlier Analysis for (a) hot and coil spots assessment of repeated oil spill incidents and (b) quantity discharged in each spill. 
quantity spills respectively. The LMi Z-score (Local Moran I) represents the significant level showing that most spills (quantity) are between $-1.0-1.0$ and $>2.0$ at 0.05 significant levels. In this result, it is clear with the aid of Figure 7(b) that the large quantity spills are closer to communities compared to the smaller ones. Figure 7(a) on the other hand, shows sites with high and low incidents for the oil spills in the studied communities. The "HH" locations are places where there has been consecutive spill occurance in the 24 years under examination, likewise the "LL" locations are places with less repeated spill incidents. The "HL" and "LH" are outliers describing locations with either few repeated spills or more, but not clustered.

\subsection{Exposure Susceptibility}

Since exposure takes place through direct and indirect contact with contaminated surfaces, the receptor (human population) must be in close proximity or have access to contaminant's pathway (see Figure 8). As a result, the communities with multiple cases of oil spill incidents stand greater chance of exposures through contaminated water, air and soil. Usually exposure pathways occur through ingestion, inhalation and dermal contact with contaminated environmental media over time. These exposure pathways can occur simultaneously or separately depending on the type and method of land use being undertaken e.g. farming, fishing, hunting, wild gathering and sourcing for water from contaminated abstraction points [50]. Table A1 presents land-use potential receptors, estimation of exposure duration and averaging time proposed in Shittu [50]. Each of these pathways is measured to determine the rate of exposure via individual or collective pathways, in order to ascertain the degree of exposure and risk posed to particular receptor(s). Table A2 gives guideline for target and intervention values for some aromatic hydrocarbons allowed by the Environmental Guideline and Standard for Petroleum Industries in Nigeria (EGASPIN) published by the DPR in 2002. Target and intervention values according to [52] are values for determining concentration or threshold levels of hydrocarbon contaminants in soil and water. The intervention value triggers remediation protocol or indicate a critical value to which the site must be remediated, while the target value signify the value which a site must not exceed [51] [63].

In deciding exposure scenarios, the concept of contaminated land is adopted to provide basis for establishing source-pathways-receptor relationship. Here, the historic oil spill sites conform to the UK's definition of contaminated land as described in Part IIA of the Environmental Protection Act, 1990. Figure 7 includes exposure analysis in terms of its impact over several factors such as human dwellings and Land use land cover (LULC) of

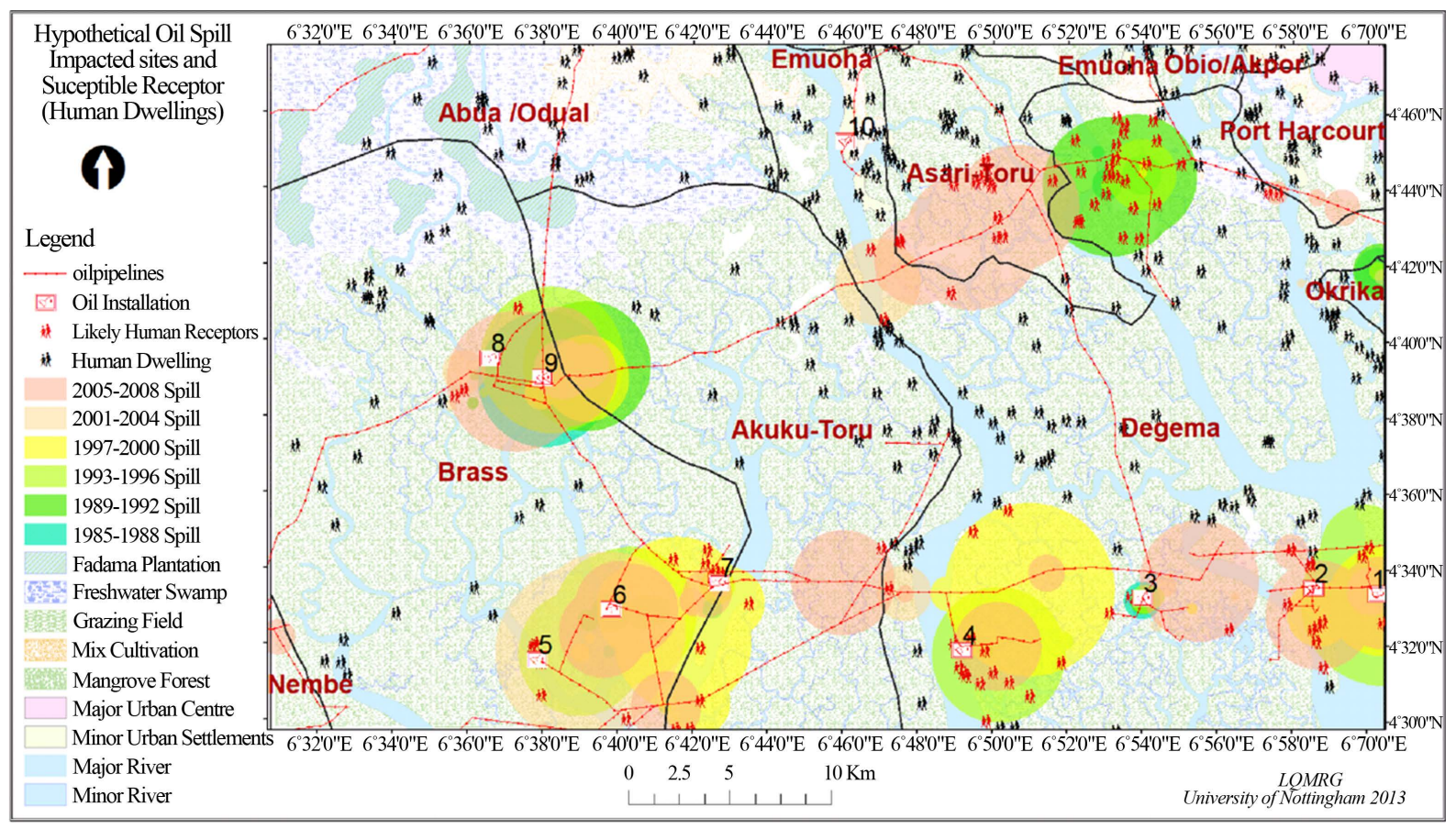

Figure 8. Oil Spill Impacted areas (communities) indicating period of spill incident and location of possible susceptible communities (human receptors). 
the study site including freshwater swamp, plantations, mangrove forests, urban settlements (major and minor), and rivers (major and minor). Even human dwelling and resources are exposed to the oil spill incidents located near or far from oil installation and pipelines as shown in Figure 7. The exposure is related to the distance of the communities from the oil spill incident sites that happened during different time-periods from 1985 to 2008, demonstrated in 4 years slots. Human symbol illustrates the settlement communities in the figure and red line symbolises the pipelines network while oil installation is represented with red box.

\section{Discussion}

A total of 59 communities were found to have had one or more spill incidents at one time or another in the period under study. The communities listed in Table 2 are arranged in order of severity (frequency) and shown in Figure 8 to indicate susceptibility, which can be influenced by: a) repeated occurrence of oil spill incidents, b) proximity and presence of source of hydrocarbon discharge and c) land use exposure opportunities. These communities represent about $15.8 \%$ of communities in the study area with a population of 168,747 , being $13.5 \%$ of entire population in the study area. Collectively they had 443 spill incidents and discharged a total of 129,578 bbl of crude oil from 1985-2008 (Table 1).

There is an indication of severe oil pollution in communities with multiple spill incidents. This is supported by the ability of some hydrocarbon components to persist longer in the environment thereby increasing the concentration of none degradable and trapped hydrocarbons in the environment [40] [51]. Although the affected sites may seem like fixed-point hazards, oil plume can migrate to adjourning land areas through surface and subsurface pathways. The United Nations report on the assessment of polluted sites in Ogoni-land revealed high concentrations of Total Petroleum Hydrocarbon (TPH) in samples collected several meters away from discharge points [51]. This information is important because the people depend on subsistence lifestyles of farming, gathering, fishing, hunting etc. and may be in constant contact with hydrocarbon contaminants in soils, water and air in their daily land use activities, which can make them vulnerable to unnecessary exposure opportunities and increase their susceptibility to health risks associated with hydrocarbon contaminants over time. The exposure duration relative to age, sex and type of land use has been estimated in Table A1 while Table A2 indicates target and intervention values legally allowed for benzene, toluene, ethylbenzene and xylene in ground water and soil sediments by the regulatory agency (DPR).

Although it is difficult to separate acts of political sabotage from theft, agitation for resource control and environmental movement in the Niger Delta struggle, has become intertwined and can only be resolved if the political, social, environmental and economic issues generated by uneven distribution of the cost and benefit of oil production are treated holistically. Perhaps this is why communities located in and around oil installation tolerate or participate in pipeline interdiction for either monetary gain or in protest. In addition, the nature of cluster of large quantity oil spills within $100 \mathrm{~m}$ revealed by the spatial analysis methods, and the theissen polygon allocation of spill sites supports community involvement. Also the presence of waterways and river channels in the creeks can provide easy access, which may encourage theft and evacuation of stolen crude oil for sale to artisanal (locally made) refineries or international black market.

Thus, results presented analysis of four techniques in Niger Delta region. Average nearest neighbourhood showed that the probability of oil spill distribution is a cluster distribution for the oil spills in the region (ratio < 1 with index value 0.19). The Getis-Ord General G tests indicated significant cluster of high quantity spills within every $400 \mathrm{~m}$ of a spill sites. The Moran's I index indicated the cluster pattern of the oil spills value ranges from $0.396-3.83$ at interval of $200 \mathrm{~m}$. Outlier method analysed the quantity of oil spills incident in the region and frequency of the oil spill incidents. The cause of oil spills notwithstanding, it is obvious that the pipeline monitoring system of oil companies has not been effective. Otherwise the cluster pattern of large quantity of oil spill sites would be minimal, except if the remote nature of the area hinders rapid response time, and/or presents difficulties for regular pipeline integrity management.

\section{Conclusions}

The aim of the study was to use geo-spatial analytical techniques to determine and assess the distribution pattern and susceptibility of communities living near oil facilities. Four techniques were used in the analysis to identify communities that are susceptible to oil spills in the study area.

- The average neighbourhood index indicated oil spill distributions to be significantly clustered while the Ge- 
tis-Ord General G-test technique showed significant cluster of high quantity spills at every $400 \mathrm{~m}$ within the study sites. Spatial autocorrelation (global Moran's $I$ ) on the other hand inferred that large quantities of oil spills are found within $100 \mathrm{~m}$ and low quantities of oil spills at farthest distance.

- The potential effect of oil pollution on human health is of great concern due to impact of oil spills in social, physical and economic terms. The health condition of people living in the area is at risk because of their daily interactions with contaminated environmental media while conducting their socio-economic land use activities. Although some of the people may have the choice of relocation, others may have no option other than to continue using the same contaminated space because of land scarcity and poverty.

- According to the pattern of spill distribution, pipeline monitoring and response plans can be centralised along the hotspots or cluster points where settlements exist. As a result, geospatial technology can be used to map pipeline distribution, pattern and proximity to sensitive environmental receptors in the region, and identify the type of land use practice of communities located along pipelines routes.

- Thus, results from this study can be useful to oil regulators and operators in addressing future occurrences. It may also be useful to consider alternative location by relocating oil facilities to minimize impact on nearby communities.

- A framework for integrating oil producing communities in oil production decision-making process would give the people a sense of belonging and motivate them to fight against interdiction of oil facilities, and by extension reduce the rate of oil spill incidents and oil pollution.

- The oil company's environmental standards must be regulated by government, which must enforce "best available technology" and "good oilfield practice" as well as educate oil producing communities on the environmental impact of oil spill and risks of prolonged exposure to petroleum hydrocarbons.

\section{Acknowledgements}

Some procedures presented in this paper were developed as part of a $\mathrm{PhD}$ research programme by the main author Shittu Whanda Ja'afaru while at the School of Geography, University of Nottingham. The authors would like to acknowledge the Departments of Petroleum Resources in Nigeria for their intermediary role in data gathering, the Nigerian National Petroleum Corporation, the National Petroleum Investment Management Services, staff of Shell Petroleum Development Company for their assistance and the Petroleum Technology Development Fund (PTDF) Abuja for funding the PhD.

\section{References}

[1] Chrisman, N. (2001) Exploring Geographical Information Systems. 2nd Edition, Wiley, New York.

[2] Steiner, R. (2010) Double Standard: Shell Practices in Nigeria Compared with International Standards to Prevent and Control Pipeline Oil Spills and the Deepwater Horizon Oil Spill. Milieudefensie, Amsterdam, 11-15.

[3] Serra-Sogas, N., O’Hara, P.D., Canessa, R., Keller, P. and Pelot, R. (2008) Visualization of Spatial Patterns and Temporal Trends for Aerial Surveillance of Illegal Oil Discharges in Western Canadian Marine Waters. Marine Pollution Bulletin, 56, 825-833. http://dx.doi.org/10.1016/j.marpolbul.2008.02.005

[4] Grace, J.D. and Hart, G.F. (1990) Urengoy Gas Field—USSR West Siberian Basin, Tyumen District.

[5] Saiko, T. (2001) Environmental Crises: Geographical Case Studies in Post-Socialist Eurasia. Pearson Education Limited, England.

[6] Exxon Mobil (2003) Spill Prevention and Response in Risk Management and Emergency Preparedness. http://corporate.exxonmobil.com/en/environment/emergency-preparedness/spill-prevention-and-response/valdez-oil-sp ill

[7] Exxon Mobil (2003) Spill Performance in Environmental Performance. http://corporate.exxonmobil.com/en/environment/environmental-performance/spill-performance/overview

[8] Short, J. (2003) Long-Term Effects of Crude Oil on Developing Fish: Lessons from the Exxon Valdez Oil Spill. Energy Sources, 25, 509-517. http://dx.doi.org/10.1080/00908310390195589

[9] Maki, A.W. (1991) The Exxon Valdez Oil Spill: Initial Environmental Impact Assessment. Part 2. Environmental Science \& Technology, 25, 24-29. http://dx.doi.org/10.1021/es00013a001

[10] Pritchard, P.H., Mueller, J.G., Rogers, J.C., Kremer, F.V. and Glaser, J.A. (1992) Oil Spill Bioremediation: Experiences, Lessons and Results from the Exxon Valdez Oil Spill in Alaska. Biodegradation, 3, 315-335. http://dx.doi.org/10.1007/BF00129091 
[11] O’Hara, P.D. and Morgan, K.H. (2006) Do Low Rates of Oiled Carcass Recovery in Beached Bird Surveys Indicate Low Rates of Ship-Source Oil Spills. Marine Ornithology, 34, 133-140.

[12] Burek, K.A., Gulland, F.M.D. and O’Hara, T.M. (2008) Effects of Climate Change on Arctic Marine Mammal Health. Ecological Applications, 18, S126-S134. http://dx.doi.org/10.1890/06-0553.1

[13] UNEP (2011) Environmental Assessment of Ogoniland, Executive Summary, 1-12. http://www.zaragoza.es/contenidos/medioambiente/onu/issue06/1130-eng-sum.pdf

[14] Veiga, F., Zapata, J.M., Marcos, M.L.F. and Alvarez, E. (2001) Dynamics of Glyphosate and Aminomethylphosphonic Acid in a Forest Soil in Galicia, North-West Spain. Science of the Total Environment, 271, 135-144. http://dx.doi.org/10.1016/S0048-9697(00)00839-1

[15] Kondo, M.C., Gross-Davis, C.A., May, K., Davis, L.O., Johnson, T., Mallard, M., Gabbadon, A., Sherrod, C. and Branas, C.C. (2014) Place-Based Stressors Associated with Industry and Air Pollution. Health \& Place, 28, 31-37. http://dx.doi.org/10.1016/j.healthplace.2014.03.004

[16] Etkin, D.S. (2001) Analysis of Oil Spill Trends in the United States and Worldwide. International Oil Spill Conference Proceedings, 2001, 1291-1300. http://dx.doi.org/10.7901/2169-3358-2001-2-1291

[17] Burgherr, P. (2007) In-Depth Analysis of Accidental Oil Spills from Tankers in the Context of Global Spill Trends from All Sources. Journal of Hazardous Materials, 140, 245-256. http://dx.doi.org/10.1016/j.jhazmat.2006.07.030

[18] O’Rourke, D. and Sarah, C. (2003) Just Oil? The Distribution of Environmental and Social Impacts of Oil Production and Consumption. Annual Review of Environment and Resources, 28, 587-617. http://dx.doi.org/10.1146/annurev.energy.28.050302.105617

[19] Frynas, J.G. (2005) The False Developmental Promise of Corporate Social Responsibility: Evidence from Multinational Oil Companies. International Affairs, 81, 581-598. http://dx.doi.org/10.1111/j.1468-2346.2005.00470.x

[20] Adekola, O., Mitchell, G. and Grainger, A. (2015) Inequality and Ecosystem Services: The Value and Social Distribution of Niger Delta Wetland Services. Ecosystem Services, 12, 42-54. http://dx.doi.org/10.1016/j.ecoser.2015.01.005

[21] Ogwu, F.A. (2011) Challenges of Oil and Gas Pipeline Network and the Role of Physical Planners in Nigeria. FORUM (International Journal of Post Graduate Studies), 10, 41-51.

[22] Bamberger, M. and Oswald, R.E. (2012) Impacts of Gas Drilling on Human and Animal Health. New Solutions: A Journal of Environmental and Occupational Health Policy, 22, 51-77. http://dx.doi.org/10.2190/NS.22.1.e

[23] Palinkas, L.A., Petterson, J.S., Russell, J. and Downs, M.A. (1993) Community Patterns of Psychiatric Disorders after the Exxon Valdez Oil Spill. American Journal of Psychiatry, 150, 1517-1523. http://dx.doi.org/10.1176/ajp.150.10.1517

[24] Gill, D.A., Picou, J.S. and Ritchie, L.A. (2011) The Exxon Valdez and BP Oil Spills: A Comparison of Initial Social and Psychological Impacts. American Behavioral Scientist, 56, 3-23.

[25] Incardona, J.P., Collier, T.K. and Scholz, N.L. (2011) Oil Spills and Fish Health: Exposing the Heart of the Matter. Journal of Exposure Science and Environmental Epidemiology, 21, 3-4. http://dx.doi.org/10.1038/jes.2010.51

[26] Solomon, G.M. and Janssen, S. (2010) Health Effects of the Gulf Oil Spill. JAMA, 304, 1118-1119. http://dx.doi.org/10.1001/jama.2010.1254

[27] Onwurah, I.N.E., Ogugua, V.N., Onyike, N.B., Ochonogor, A.E. and Otitoju, O.F. (2007) Crude Oil Spills in the Environment, Effects and Some Innovative Clean-Up Biotechnologies. International Journal of Environmental Research, 1, 307-320.

[28] Achebe, C.H., Nneke, U.C. and Anisiji, O.E. (2012) Analysis of Oil Pipeline Failures in the Oil and Gas Industries in the Niger Delta Area of Nigeria. Proceeding of International MultiConference of Engineers and Computer Scientists, Hong Kong, 14-16 March 2012.

[29] Kandiyoti, R. (2012) Pipelines: Flowing Oil and Crude Politics. IB Tauris, London.

[30] Ambituuni, A., Hopkins, P., Amezaga, J.M., Werner, D. and Wood, J.M. (2015) Risk Assessment of Petroleum Product Pipeline in Nigeria: The Realities of Managing Problems of Theft/Sabotage. Safety and Security Engineering, 6, 113.

[31] Alawode, A.J. and Ogunleye, I.O. (2011) Maintenance, Security, and Environmental Implications of Pipeline Damage and Ruptures in the Niger Delta Region. The Pacific Journal of Science and Technology, 12, 565-573.

[32] Anifowose, B., Lawler, D.M., Van der Horst, D. and Chapman, L. (2012) Attacks on Oil Transport Pipelines in Nigeria: A Quantitative Exploration and Possible Explanation of Observed Patterns. Applied Geography, 32, 636-651. http://dx.doi.org/10.1016/j.apgeog.2011.07.012

[33] Mohamed, Y. (2012) Blast Rocks Egypt’s Gas Pipeline to Israel, Jordan. Reuters. http://www.reuters.com/article/2012/07/22/us-egypt-pipeline-idUSBRE86L00T20120722 
[34] Opukri, C.O. and Ibaba, I.S. (2008) Oil Induced Environmental Degradation and Internal Population Displacement in the Nigeria’s Niger Delta. Journal of Sustainable Development in Africa, 10, 173-193.

[35] Shell Petroleum Development Company (2014) Oil Spill Data. Shell Petroleum Development Company. http://www.shell.com.ng/environment-society/environment-tpkg/oil-spills.html

[36] Akpomuvie, O. (2011) Tragedy of Commons: Analysis of Oil Spillage, Gas Flaring and Sustainable Development of the Niger Delta of Nigeria. Journal of Sustainable Development, 4, 200-210.

[37] Adebayo, A. and Dada, A.S. (2008) An Evaluation of the Causes of Oil Pipeline Incidents in Oil and Gas Industries in Niger Delta Region of Nigeria. Journal of Engineering and Applied Sciences, 3, 279-281.

[38] Reible, D. (2010) After the Oil Is No Longer Leaking. Environmental Science \& Technology, 44, 5685-5686. http://dx.doi.org/10.1021/es1020372

[39] Fingas, M. (2012) The Basics of Oil Spill Cleanup. 2nd Edition, CRC Press, Boca Raton. http://dx.doi.org/10.1201/b13686

[40] Chen, J. and Denison, M.S. (2011) The Deepwater Horizon Oil Spill: Environmental Fate of the Oil and the Toxicological Effects on Marine Organisms. Horizon (Indicated in Red). Journal of Young Investigators, 21, 84-95.

[41] National Population Commission (2006) Population and Housing Census of the Federal Republic of Nigeria 2006 Census: Priority Tables. National Population Commission, Abuja.

[42] Aaron, K.K. (2005) Perspective: Big Oil, Rural Poverty, and Environmental Degradation in the Niger Delta Region of Nigeria. Journal of Agricultural Safety and Health, 11, 127-134. http://dx.doi.org/10.13031/2013.18178

[43] Forest, J.J.F. and Sousa, M.V. (2006) Oil and Terrorism in the New Gulf: Framing U.S. Energy and Security Policies for the Gulf of Guinea. Lexington Books.

[44] Adekola, O. and Mitchell, G. (2011) The Niger Delta Wetlands: Threats to Ecosystem Services, Their Importance to Dependent Communities and Possible Management Measures. International Journal of Biodiversity Science, Ecosystem Services \& Management, 7, 50-68. http://dx.doi.org/10.1080/21513732.2011.603138

[45] United Nations Development Programme (2006) Niger Delta Human Development Report. United Nations Development Programme, Lagos.

[46] Watts, M., Okonta, I. and Kemedi, D.V. (2004) Economies of Violence: Petroleum, Politics and Community Conflict in the Niger Delta, Nigeria. Niger Delta: Economies of Violence: Institute of International Studies, University of California, Berkeley; The United States Institute of Peace, Washington DC; Our Niger Delta, Port Harcourt, Nigeria.

[47] Yakubu, L. (2008) Nigeria Loses N5.8b Daily to Gas Flaring. The Guardian, 5th August.

[48] Adamu, B., Tansey, K. and Ogutu, B. (2015) Using Vegetation Spectral Indices to Detect Oil Pollution in the Niger Delta. Remote Sensing Letters, 6, 145-154. http://dx.doi.org/10.1080/2150704X.2015.1015656

[49] Shittu, W. (2014) Mapping of Oil Spill Human Health Risk in Rivers State, Niger Delta, Nigeria. Ph.D. Thesis, Geography, University of Nottingham, Nottingham. http://eprints.nottingham.ac.uk/14115/ http://ethos.bl.uk/OrderDetails.do?uin=uk.bl.ethos.632453

[50] United Nations Environment Programme (2011) Environmental Assessment of Ogoniland. United Nations Environment Programme, Nairobi.

[51] Odey, F.O., Eneji, R.I. and Pan, L. (2010) Socio-Economic Impacts of Oil Development in the Niger-Delta, Nigeria. Annals of Humanities and Development Studies, 1.

[52] Okonkwo, E.C. (2014) Oil Spills in Nigeria: Are There Social and Economic Impacts? International Oil Spill Conference Proceedings, 2014, 300289. http://dx.doi.org/10.7901/2169-3358-2014-1-300289.1

[53] Ratcliffe, J.H. and Taniguchi, T.A. (2008) Is Crime Higher around Drug-Gang Street Corners? Two Spatial Approaches to the Relationship between Gang Set Spaces and Local Crime Levels. Crime Patterns and Analysis, 1, 1739.

[54] Mitchell, A. (2012) The ESRI Guide to GIS Analysis: Modelling Suitability, Movement, and Interaction. Vol. 3, ESRI Press, California.

[55] Ebdon, D. (1985) Statistics in Geography. 2nd Edition, Blackwell Publishing, Hoboken.

[56] Mitchell, A. (2009) The ESRI Guide to GIS Analysis: Spatial Measurement and Statistics. ESRI Press, California.

[57] Getis, A. and Ord, J.K. (1992) The Analysis of Spatial Association by Use of Distance Statistics. Geographical Analysis, 24, 189-206. http://dx.doi.org/10.1111/j.1538-4632.1992.tb00261.x

[58] Ord, J.K. and Getis, A. (1995) Local Spatial Autocorrelation Statistics: Distributional Issues and an Application. Geographical Analysis, 27, 286-306. http://dx.doi.org/10.1111/j.1538-4632.1995.tb00912.x

[59] Mashima, D., Kobourov, S.G. and Hu, Y.F. (2012) Visualizing Dynamic Data with Maps. IEEE Transactions on Visualization and Computer Graphics, 18, 1424-1437. http://dx.doi.org/10.1109/TVCG.2011.288 
[60] Jerrett, M., Burnett, R., Goldberg, M., Sears, M., Krewski, D., Catalan, R., Kanaroglou, P., Giovis, C. and Finkelstein, N. (2003) Spatial Analysis for Environmental Health Research: Concepts, Methods, and Examples. Journal of Toxicology and Environmental Health, Part A, 66, 1783-1810. http://dx.doi.org/10.1080/15287390306446

[61] Amnesty International Publication (2013) Bad Information: Oil Spill Investigations in the Niger Delta. International Secretariat, Amnesty International Publications, London.

[62] IUCN-NDP (2013) Sustainable Remediation and Rehabilitation of Biodiversity and Habitats of Oil Spill Sites in the Niger Delta.

https://cmsdata.iucn.org/downloads/ndp annex iii final international standards inc biodiversity biophysical social param.pdf

[63] EGASPIN (2002) Environmental Guidelines and Standards for the Petroleum Industry in Nigeria. Revised Edition, Department of Petroleum Resources, Lagos. 


\section{Appendix}

Table A1. Land-use potential receptors, estimated exposure duration and averaging time (Shittu, 2014).

\begin{tabular}{|c|c|c|c|c|c|}
\hline No. & Activities & Possible exposure route & Potential receptor & $\begin{array}{l}\text { Est. exposure duration and } \\
\text { frequency per year }\end{array}$ & $\begin{array}{c}\text { Est. averaging time } \\
\text { for } 30 \text { yrs adult and } \\
6 \text { yrs child }\end{array}$ \\
\hline 1 & Farming & $\begin{array}{l}\text { i) Inhalation of contaminated dust particles } \\
\text { during soil tilling. } \\
\text { ii) Ingestion of contaminated farm produce } \\
\text { or soil ingestion by means of } \\
\text { substance-to-hand-to-mouth (IPCS, 2005). } \\
\text { iii) Dermal contact through deposition of } \\
\text { suspended particles on parts of the body. }\end{array}$ & $\begin{array}{l}\text { Members of the family } \\
\text { who provide farm labour, } \\
\text { i.e. children and adults. }\end{array}$ & $\begin{array}{c}E D=5 \text { hrs/day, } 5 \text { days/week for } 8 \\
\text { months ( } 240 \text { days) being the length of } \\
\text { the farming season. } \\
E F=\frac{5}{7} x(8 \times 30)=171 \text { day } / \text { year } \\
8 \text { months duration of cultivation }\end{array}$ & $\begin{array}{c}\text { Adults' AT } 171 \text { days } \times \\
30 \text { yrs }=5130 \text { days } \\
\text { Children's AT } \\
171 \text { days } \times 6 \text { yrs }=1026 \\
\text { days }\end{array}$ \\
\hline 2 & Fishing & $\begin{array}{l}\text { i) Dermal contact: direct and indirect skin } \\
\text { contact with contaminated water during } \\
\text { fishing. Indirect contact transfers } \\
\text { contaminants from soaked cloth to skin. } \\
\text { ii) Inhalation of volatile hydrocarbons from } \\
\text { a freshly-spilled surface can be significant. } \\
\text { Inhalation during fish smoking (a } \\
\text { preservation technique with heat and } \\
\text { smoke). Release trapped hydrocarbons in } \\
\text { fish tissue into the ambient air for inhalation. } \\
\text { iii) Ingestion can occur by ingesting } \\
\text { contaminated water and fish. Consumption } \\
\text { of contaminated fish is a potential source } \\
\text { of exposure. }\end{array}$ & $\begin{array}{l}\text { Children and adults } \\
\text { involved in fishing, fish } \\
\text { preparation, and fish } \\
\text { consumption. }\end{array}$ & $\begin{array}{l}E D=6 \text { hrs/day, } 5 \text { days/week for a year. } \\
\qquad E F=\frac{5}{7} x(365)=261 \text { day } / \text { year }\end{array}$ & $\begin{array}{c}\text { Adults' AT }=261 \times 30 \\
=7830 \\
\text { Children's AT }=261 \times \\
6=1566\end{array}$ \\
\hline 3 & Hunting & $\begin{array}{l}\text { i) Dermal contact may occur when a hunter's } \\
\text { trap site becomes polluted. Direct and } \\
\text { indirect contact via deposition of suspended } \\
\text { hydrocarbons on skin or from cloth to skin, } \\
\text { as he travels through different layers of } \\
\text { polluted surfaces. } \\
\text { ii) Ingestion from surface-to-hand-to-mouth } \\
\text { or ingesting contaminated wild fruits. } \\
\text { iii) Inhalation during movement from one } \\
\text { trap site to another is possible since it } \\
\text { involves travelling within and between } \\
\text { changing layers of polluted air. }\end{array}$ & $\begin{array}{l}\text { The receptors are } \\
\text { children and adults } \\
\text { performing this activity. }\end{array}$ & $\begin{array}{l}E D=5 \text { hrs/day, } 5 \text { days/week for a year. } \\
\qquad E F=\frac{5}{7} x(365)=261 \text { day } / \text { year }\end{array}$ & $\begin{array}{c}\text { Adults' AT }=261 \times 30 \\
=7830 \\
\text { Children's AT }=260 \times \\
6=1566\end{array}$ \\
\hline 4 & Gathering & $\begin{array}{l}\text { i) Inhalation when gathering on or near a } \\
\text { polluted site; inhalation of contaminated air } \\
\text { or dust particles within a polluted } \\
\text { microenvironment is possible. Also, burning } \\
\text { of wood can release trapped hydrocarbons in } \\
\text { plant tissue. } \\
\text { ii) Dermal contact can occur while walking } \\
\text { through polluted sites or being in contact } \\
\text { with contaminated surfaces. Suspended } \\
\text { hydrocarbons can deposit on leaves and be } \\
\text { transferred while walking past. } \\
\text { iii) Ingestion is not common in this activity } \\
\text { except if wild contaminated fruits are } \\
\text { consumed or surface-to-hand-to-mouth } \\
\text { contact occurs. }\end{array}$ & $\begin{array}{l}\text { Women and children are } \\
\text { the critical receptors in } \\
\text { this activity because they } \\
\text { are more involved with } \\
\text { cooking and gathering. }\end{array}$ & $\begin{array}{l}E D=5 \text { hrs/day, } 5 \text { days/week for a year. } \\
\qquad E F=\frac{5}{7} x(365)=261 \text { day } / \text { year }\end{array}$ & $\begin{array}{c}\text { Adults' AT }=261 \times 30 \\
=7830 \\
\text { Children's AT }=261 \times \\
6=1566\end{array}$ \\
\hline
\end{tabular}

Table A2. EGASPIN target and intervention values for soil and groundwater (EGASPIN, 2002) [63].

\begin{tabular}{|c|c|c|c|c|}
\hline \multirow{2}{*}{$\begin{array}{l}\text { Substance } \\
\text { Aromatic }\end{array}$} & \multirow{2}{*}{\multicolumn{2}{|c|}{$\begin{array}{c}\text { Soil/sediment } \\
\text { (mg/kg dry material) }\end{array}$}} & \multirow{2}{*}{\multicolumn{2}{|c|}{$\begin{array}{c}\text { Groundwater } \\
(\mu \mathrm{g} / 1)\end{array}$}} \\
\hline & & & & \\
\hline Benzene & 0.05 & 1 & 0.2 & 30 \\
\hline Ethylbenzene & 0.05 & 50 & 0.2 & 150 \\
\hline Toluene & 0.05 & 130 & 0.2 & 1000 \\
\hline Xylene & 0.05 & 25 & 0.2 & 70 \\
\hline
\end{tabular}




\section{Submit or recommend next manuscript to SCIRP and we will provide best service for you:}

Accepting pre-submission inquiries through Email, Facebook, LinkedIn, Twitter, etc.

A wide selection of journals (inclusive of 9 subjects, more than 200 journals)

Providing 24-hour high-quality service

User-friendly online submission system

Fair and swift peer-review system

Efficient typesetting and proofreading procedure

Display of the result of downloads and visits, as well as the number of cited articles

Maximum dissemination of your research work

Submit your manuscript at: http://papersubmission.scirp.org/ 